\title{
Pseudoxanthomonas suwonensis sp. nov., isolated from cotton waste composts
}

Correspondence
Soon-Wo Kwon
swkwon@rda.go.kr

The genus Pseudoxanthomonas, which was first proposed by Finkmann et al. (2000), is placed in the family Xanthomonadaceae, order Xanthomonadales, class Gammaproteobacteria and phylum Proteobacteria (Garrity \& Holt, 2001) in the taxonomic hierarchy. This genus is closely related phylogenetically with the genera Xanthomonas, Xylella and Stenotrophomonas (Finkmann et al., 2000; Chen et al., 2002; Thierry et al., 2004; Yang et al., 2005). However, members of the genus Pseudoxanthomonas can be differentiated from members of these related genera by the reduction of nitrate but not nitrite and the lack of $\mathrm{C}_{13: 0}$ iso $3-\mathrm{OH}$ fatty acid

Published online ahead of print on 25 November 2005 as DOI 10.1099/ijs.0.63749-0.

The GenBank/EMBL/DDBJ accession number for the $16 \mathrm{~S}$ rRNA gene sequence of strain $4 M 1^{\top}$ is $A Y 927994$.

Tables showing physiological properties of strains $4 \mathrm{M}^{\top}, 4 \mathrm{M} 9$ and $4 \mathrm{M} 12$ on the basis of API 20NE, API ZYM and Biolog GN2 tests, denitrification reactions of isolates and Pseudoxanthomonas reference strains and cellular fatty-acid profiles of strain $4 \mathrm{M} 1^{\top}$ and other species in the genus Pseudoxanthomonas together with a phase-contrast micrograph of $4 \mathrm{M} 1^{\top}$ are available in IJSEM Online.
(Yang et al., 1993; Finkmann et al., 2000; Assih et al., 2002). The genus Pseudoxanthomonas currently comprises six species, Pseudoxanthomonas broegbernensis (type species; Finkmann et al., 2000), P. taiwanensis (Chen et al., 2002), P. mexicana (Thierry et al., 2004), P. japonensis (Thierry et al., 2004), P. koreensis (Yang et al., 2005) and P. daejeonensis (Yang et al., 2005).

In the course of studying the bacterial diversity associated with cotton waste composts, several strains were isolated, showing a yellow colony colour on CASO agar (DSMZ medium no. 220; http://www.dsmz.de/media/media.htm) incubated at $30^{\circ} \mathrm{C}$. Among them, three, $4 \mathrm{M}^{\mathrm{T}}, 4 \mathrm{M} 9$ and $4 \mathrm{M} 12$, were phylogenetically distinct from the known species within the genus Pseudoxanthomonas.

Gram staining, $\mathrm{KOH}$ test and L-alanine aminopeptidase assay were performed by using a Gram stain kit (Difco), $3 \%$ (w/v) KOH (Buck, 1982) and Bactident aminopeptidase (Merck), respectively. Motility was tested on motility medium of $0 \cdot 1 \%$ yeast extract, $0 \cdot 01 \% \mathrm{~K}_{2} \mathrm{HPO}_{4}$ and $0 \cdot 2 \%$ agar. Oxidative or fermentative utilization of glucose was determined in Hugh \& Leifson medium (Hugh \& Leifson, 
1953). Catalase activity was tested by $3 \%(\mathrm{v} / \mathrm{v}) \mathrm{H}_{2} \mathrm{O}_{2}$ solution. Morphology was observed using oil immersion phasecontrast microscopy after 1 day incubation on CASO agar at $30^{\circ} \mathrm{C}$. Oxidase, hydrolysis of aesculin, cellulose, starch, casein, gelatin, Tweens 20, 40 and 80 and DNA and indole production were assessed according to the methods of Smibert \& Krieg (1994). Hydrolysis of chitin (1\%, w/v) and tyrosine $(0.5 \%, \mathrm{w} / \mathrm{v})$ was tested by the appearance of a clear zone around the colonies. Urease activity was determined by the method described by MacFaddin (2000). The $\mathrm{pH}$ range ( $\mathrm{pH} 4 \cdot 0-10 \cdot 0$ at intervals of $1 \cdot 0 \mathrm{pH}$ unit) for growth was determined on CASO agar that was buffered with citratephosphate buffer or Tris/HCl (Breznak \& Costilow, 1994). Growth at various $\mathrm{NaCl}$ concentrations was investigated in CASO broth and growth at various temperatures $\left(5-50{ }^{\circ} \mathrm{C}\right)$ was measured on CASO agar. Tests using the commercial systems API ZYM, API 20NE and API 50CH (bioMérieux) were generally performed according to the manufacturer's instructions. The API ZYM tests were read after $4 \mathrm{~h}$ incubation at $30^{\circ} \mathrm{C}$ and the other API tests were read after $48 \mathrm{~h}$ at $30{ }^{\circ} \mathrm{C}$. The Biolog GN identification system was also used as recommended by the manufacturer at $30^{\circ} \mathrm{C}$. Sensitivity to antibiotics was determined with the routine disc-diffusion plate method. For the nitrate and nitrite reduction test, each isolate was inoculated into three serum bottles $(25 \mathrm{ml})$ containing $13 \mathrm{ml} \mathrm{R} 2 \mathrm{~A}$ medium, while nitrate and nitrite were added as $\mathrm{KNO}_{3}$ and $\mathrm{NaNO}_{2}$ at concentrations of $10 \mathrm{mM}$. The reduction of nitrate and nitrite was monitored by ion chromatograph (model 790 personal IC; Metrohm) equipped with a conductivity detector and anion-exchange column (Metrosep Anion Supp 4; Metrohm).

Fatty acid methyl esters were extracted and prepared by the standard protocol of the Microbial Identification system (MIDI; Microbial ID) after cells were grown on tryptic soy agar for $24 \mathrm{~h}$ at $30^{\circ} \mathrm{C}$. Isoprenoid quinones were analysed by HPLC as described previously (Groth et al., 1996). The DNA $\mathrm{G}+\mathrm{C}$ content (mol\%) was determined by HPLC analysis of deoxyribonucleosides as described by Mesbah et al. (1989) using a reverse-phase column (Supelcosil LC-18-S; Supelco).

The 16S rRNA genes were amplified (Kwon et al., 2003) and directly sequenced (Hiraishi, 1992). To establish the phylogenetic positions of the strains, the nearly complete $16 \mathrm{~S}$ rRNA gene sequence of strain $4 \mathrm{M}^{\mathrm{T}}$ comprising $1509 \mathrm{nt}$ was determined and the phylogenetic tree was constructed together with the sequences of related taxa obtained from GenBank. The sequences were aligned by using the MEGALIGN program of DNASTAR. An evolutionary distance matrix was generated as described by Jukes \& Cantor (1969). The evolutionary tree for the datasets was inferred from the neighbour-joining method of Saitou \& Nei (1987) by using MEGA version 2.1 (Kumar et al., 2001). The stability of relationships was assessed by performing bootstrap analyses of the neighbour-joining data based on 1000 resamplings.

DNA-DNA hybridization was carried out as a filterhybridization method described by Seldin \& Dubnau (1985). Probe labelling was conducted by using the non-radioactive DIG-High prime system (Roche) and hybridized DNA was visualized using the DIG luminescent detection kit (Roche). DNA-DNA relatedness was quantified by using a densitometer (Bio-Rad).

The strains were aerobic, motile, Gram-negative rods, generally $0.3-0.5 \times 1 \cdot 2-3.0 \mu \mathrm{m}$ in size (Supplementary Fig. S1 available in IJSEM Online). Colonies were round, yellow and convex with entire margins. These strains were positive for oxidase and catalase, $\mathrm{KOH}$ ring test, hydrolysis of aesculin, Tween 20, tyrosine and DNA. They showed negative reactions in tests for arginine dihydrolase, hydrolysis of casein, cellulose, chitin, Tween 40, starch and urea and indole production. Optimal growth of all the strains occurred at $30{ }^{\circ} \mathrm{C}$ and they grew in the range of $10-45^{\circ} \mathrm{C}$. They grew in the $\mathrm{pH}$ range of $6 \cdot 0-8 \cdot 0$ and in the presence of $5 \%(\mathrm{w} / \mathrm{v}) \mathrm{NaCl}$, but not at $7 \% \mathrm{NaCl}$.

The hydrolysis of gelatin and Tween 80 showed discrepancies between the different test methods. Therefore, the conventional test results were used (Table 1). In API 50CH, none of the tested strains showed any reactions except for the hydrolysis of aesculin, indicating that this test kit was inappropriate for testing the metabolic properties of these strains. Other metabolic properties are shown in Supplementary Table S1 (available in IJSEM Online). In nitrate and nitrite reduction tests, two isolates, $4 \mathrm{M1}^{\mathrm{T}}$ and $4 \mathrm{M} 9$, revealed the reduction of nitrate to nitrite but no nitrite reduction, whereas isolate $4 \mathrm{M} 12$ showed nitrite reduction but no reduction of nitrate to nitrite (results are available in Supplementary Table S2 in IJSEM Online).

The major fatty acid of these isolates was iso- $\mathrm{C}_{15: 0}$. The comparison of the fatty-acid profiles for seven Pseudoxanthomonas species are shown in Supplementary Table S3 (available in IJSEM Online). Generally, Pseudoxanthomonas strains have been reported not to have iso- $\mathrm{C}_{13: 0} 3-\mathrm{OH}$ (Thierry et al., 2004). However, these three novel strains had trace amounts $(0 \cdot 1-0 \cdot 2 \%)$ of iso- $\mathrm{C}_{13: 0} 3-\mathrm{OH}$. The predominant isoprenoid quinone of the tested strains was Q-8. The DNA G + C content of the strains was $66 \cdot 6-68 \cdot 4 \mathrm{~mol} \%$.

Strain $4 \mathrm{M1}^{\mathrm{T}}$ was phylogenetically clustered in the genus Pseudoxanthomonas (Fig. 1) and the sequence similarity was 96.9-99.0 \% with Pseudoxanthomonas species with validly published names. Strain $4 \mathrm{M}^{\mathrm{T}}$ showed the highest sequence similarity, 99.0 and $98.6 \%$, respectively, with $P$. koreensis T7-09 ${ }^{\mathrm{T}}$ and $P$. daejeonensis TR6- $08^{\mathrm{T}}$. The similarity of the $16 \mathrm{~S}$ rRNA gene sequences of strain $4 \mathrm{M}^{\mathrm{T}}$ to those of all other species within phylogenetically closely related genera such as Xanthomonas, Xylella and Stenotrophomonas was below $97 \%$.

DNA-DNA relatedness was assessed between strain $4 \mathrm{M}^{\mathrm{T}}$ and all known Pseudoxanthomonas species. Strain $4 \mathrm{M} 1^{\mathrm{T}}$ revealed DNA hybridization values of 98 and $95 \%$ with $4 \mathrm{M} 9$ and $4 \mathrm{M} 12$, respectively, indicating one genomic species. However, isolate $4 \mathrm{M}^{\mathrm{T}}$ showed DNA hybridization values of below $70 \%$ to all known Pseudoxanthomonas species, indicating that it represents a distinct genomic species 
Table 1. Physiological and biochemical characteristics of Pseudoxanthomonas species

Strains: 1 , P. suwonensis sp. nov. $4 \mathrm{M}^{\mathrm{T}} ; 2$, P. broegbernensis DSM $12573^{\mathrm{T}}$; 3, P. taiwanensis ATCC BAA-404 ${ }^{\mathrm{T}} ; 4$, P. mexicana AMX $28 \mathrm{~B}^{\mathrm{T}}$; 5, P. japonensis $12-3^{\mathrm{T}} ; 6$, P. koreensis $\mathrm{T} 7-09^{\mathrm{T}} ; 7$, P. daejeonensis TR6-08 ${ }^{\mathrm{T}}$. Data from Finkmann et al. (2000), Chen et al. (2002), Thierry et al. (2004), Yang et al. (2005) and this study. +, Positive; -, negative; W, weak reaction; ND, not determined.

\begin{tabular}{|c|c|c|c|c|c|c|c|}
\hline Characteristic & 1 & 2 & 3 & 4 & 5 & 6 & 7 \\
\hline Motility & + & + & - & + & + & - & + \\
\hline Optimum growth temperature $\left({ }^{\circ} \mathrm{C}\right)$ & 30 & 30 & 50 & $30-37$ & $30-37$ & 30 & 30 \\
\hline Growth at $10^{\circ} \mathrm{C}$ & + & + & - & + & + & $\mathrm{W}$ & $\mathrm{W}$ \\
\hline Growth at $42{ }^{\circ} \mathrm{C}$ & + & - & + & - & - & - & - \\
\hline Aesculin & + & + & + & + & ND & - & + \\
\hline Casein & - & - & - & + & + & + & + \\
\hline Gelatin & + & - & - & + & + & - & - \\
\hline Tween 80 & - & + & + & $+1-$ & + & $\mathrm{ND}$ & $\mathrm{ND}$ \\
\hline Urea & - & - & ND & - & ND & + & - \\
\hline D-Mannitol & - & - & ND & ND & ND & - & - \\
\hline$N$-Acetylglucosamine & + & + & ND & ND & ND & - & + \\
\hline D-Maltose & + & + & - & + & + & - & + \\
\hline Citrate & - & + & ND & - & - & - & - \\
\hline DNA G + C content $(\mathrm{mol} \%)$ & $66 \cdot 6-68 \cdot 4$ & $66 \cdot 5 \pm 0 \cdot 8$ & $70 \cdot 0 \pm 0 \cdot 1$ & $67 \cdot 8 \pm 2$ & $65 \cdot 2 \pm 1$ & $69 \cdot 5 \pm 0 \cdot 5$ & $68 \cdot 7 \pm 0 \cdot 4$ \\
\hline
\end{tabular}

(Wayne et al., 1987). The DNA-DNA hybridization values between strain $4 \mathrm{M}^{\mathrm{T}}$ and type strains of other Pseudoxanthomonas species were: 52 (P. broegbernensis), 57 ( $P$. japonensis), 62 (P. mexicana), 60 (P. taiwanensis), 58 ( $P$. koreensis), 63 (P. daejeonensis) and $56 \%$ (P. kaohsiungensis).

Although strain $4 \mathrm{M}^{\mathrm{T}}$ showed a relatively high degree of $16 \mathrm{~S}$ rRNA gene sequence similarity, it could be differentiated from other species of the genus Pseudoxanthomonas by means of DNA-DNA hybridization and a few physiological tests. In conclusion, we propose the name Pseudoxanthomonas suwonensis sp. nov. for the three novel strains.

\section{Description of Pseudoxanthomonas suwonensis sp. nov.}

Pseudoxanthomonas suwonensis (su.won.en'sis. N.L. fem. adj. suwonensis referring to Suwon region, where the bacterium was first found).

Cells are aerobic, Gram-negative, motile rods, generally $0 \cdot 3-0 \cdot 5 \times 1 \cdot 2-3 \cdot 0 \mu \mathrm{m}$ in size, occurring singly. Colonies are round, yellow and convex with entire margins. Temperature range for growth is $10-45^{\circ} \mathrm{C}$ and optimal temperature is $30{ }^{\circ} \mathrm{C}$. Growth occurs in the $\mathrm{pH}$ range of $6 \cdot 0-8 \cdot 0$ and in the

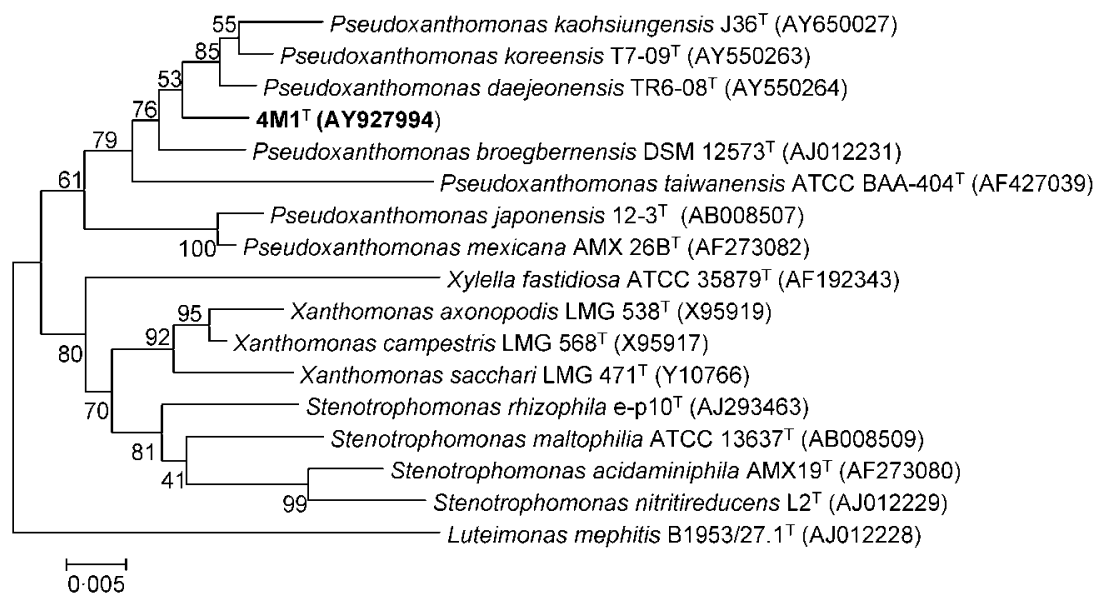

Fig. 1. Phylogenetic tree based on $16 \mathrm{~S}$ rRNA gene sequence analysis showing the relationship of the novel species to members of the genera Pseudoxanthomonas, Xanthomonas, Stenotrophomonas, Xylella and Luteimonas. The sequence of Luteimonas mephitis was used as an outgroup. Numbers at branch points indicate the percentage of bootstrap support. Bar, 5 substitutions per 1000 nt. 
presence of up to $5 \%(\mathrm{w} / \mathrm{v}) \mathrm{NaCl}$. Positive for oxidase, catalase and hydrolysis of aesculin, Tween 20, tyrosine and DNA. Negative for arginine dihydrolase, hydrolysis of casein, cellulose, chitin, Tween 40, starch and urea and indole production. The predominant isoprenoid quinone is Q-8. Principal fatty acids (greater than $5 \%$ ) are iso- $\mathrm{C}_{15: 0}$ $(30 \cdot 8 \%)$, anteiso- $\mathrm{C}_{15: 0}(13 \cdot 2 \%)$, iso- $\mathrm{C}_{16: 0}(11 \cdot 1 \%)$, iso$\mathrm{C}_{17: 1} \omega 9 c(10 \cdot 6 \%)$, iso- $\mathrm{C}_{11: 0}(7 \cdot 4 \%)$ and iso- $\mathrm{C}_{11: 0} 3-\mathrm{OH}$ $(7 \cdot 0 \%)$. The DNA G $+\mathrm{C}$ content is $66 \cdot 6-68 \cdot 4 \mathrm{~mol} \%$.

The type strain, $4 \mathrm{M}^{\mathrm{T}}\left(=\mathrm{KACC} 11320^{\mathrm{T}}=\mathrm{DSM} 17175^{\mathrm{T}}\right)$, was isolated from cotton waste composts in Korea.

\section{References}

Assih, E. A., Ouattara, A. S., Thierry, S., Cayol, J.-L., Labat, M. \& Macarie, H. (2002). Stenotrophomonas acidaminiphila sp. nov., a strictly aerobic bacterium isolated from an upflow anaerobic sludge blanket (UASB) reactor. Int J Syst Evol Microbiol 52, 559-568.

Breznak, J. A. \& Costilow, R. N. (1994). Physicochemical factors in growth. In Methods for General and Molecular Bacteriology, pp. 137-154. Edited by P. Gerhardt, R. G. E. Murray, W. A. Wood \& N. R. Krieg. Washington, DC: American Society for Microbiology.

Buck, J. D. (1982). Nonstaining (KOH) method for determination of Gram reactions of marine bacteria. Appl Environ Microbiol 44, 992-993.

Chen, M. Y., Tsay, S. S., Chen, K. Y., Shi, Y. C., Lin, Y. T. \& Lin, G. H. (2002). Pseudoxanthomonas taiwanensis sp. nov., a novel thermophilic, $\mathrm{N}_{2} \mathrm{O}$-producing species isolated from hot springs. Int J Syst Evol Microbiol 52, 2155-2161.

Finkmann, W., Altendorf, K., Stackebrandt, E. \& Lipski, A. (2000). Characterization of $\mathrm{N}_{2} \mathrm{O}$-producing Xanthomonas-like isolates from biofilters as Stenotrophomonas nitritireducens sp. nov., Luteimonas mephitis gen. nov., sp. nov. and Pseudoxanthomonas broegbernensis gen. nov., sp. nov. Int J Syst Evol Microbiol 50, 273-282.

Garrity, G. M. \& Holt, J. G. (2001). The road map to the Manual. In Bergey's Manual of Systematic Bacteriology, 2nd edn, vol. 1, pp. 119-166. Edited by D. R. Boone, R. W. Castenholz \& G. M. Garrity. New York: Springer.

Groth, I., Schumann, P., Weiss, N., Martin, K. \& Rainey, F. A. (1996). Agrococcus jenensis gen. nov., sp. nov., a new genus of actinomycetes with diaminobutyric acid in the cell wall. Int J Syst Bacteriol 46, 234-239.

Hiraishi, A. (1992). Direct automated sequencing of $16 \mathrm{~S}$ rDNA amplified by polymerase chain reaction from bacterial cultures without DNA purification. Lett Appl Microbiol 15, 210-213.
Hugh, R. \& Leifson, E. (1953). The taxonomic significance of fermentative versus oxidative metabolism of carbohydrates by various gram negative bacteria. J Bacteriol 66, 24-26.

Jukes, T. H. \& Cantor, C. R. (1969). Evolution of protein molecules. In Mammalian Protein Metabolism, pp. 21-132. Edited by H. N. Munro. New York: Academic Press.

Kumar, S., Tamura, K., Jakobsen, I. B. \& Nei, M. (2001). MEGA2: molecular evolutionary genetics analysis software. Bioinformatics $\mathbf{1 7}$, 1244-1245.

Kwon, S. W., Kim, J. S., Park, I. C., Yoon, S. H., Park, D. H., Lim, C. K. \& Go, S. J. (2003). Pseudomonas koreensis sp. nov., Pseudomonas umsongensis sp. nov. and Pseudomonas jinjuensis sp. nov., novel species from farm soils in Korea. Int J Syst Evol Microbiol 53, $21-27$.

MacFaddin, J. F. (2000). Urease test. In Biochemical Tests for Identification of Medical Bacteria, 3rd edn, pp. 424-438. Baltimore: Lippincott Williams \& Wilkins.

Mesbah, M., Premachandran, U. \& Whitman, W. B. (1989). Precise measurement of the $\mathrm{G}+\mathrm{C}$ content of deoxyribonucleic acid by high-performance liquid chromatography. Int J Syst Bacteriol 39, 159-167.

Saitou, N. \& Nei, M. (1987). The neighbor-joining method: a new method for reconstructing phylogenetic trees. Mol Biol Evol 4 406-425.

Seldin, L. \& Dubnau, D. (1985). Deoxyribonucleic acid homology among Bacillus polymyxa, Bacillus macerans, Bacillus azotofixans, and other nitrogen-fixing Bacillus strains. Int J Syst Bacteriol 35, 151-154.

Smibert, R. M. \& Krieg, N. R. (1994). Phenotypic characterization. In Methods for General and Molecular Bacteriology, pp. 607-654. Edited by P. Gerhardt, R. G. E. Murray, W. A. Wood \& N. R. Krieg. Washington, DC: American Society for Microbiology.

Thierry, S., Macarie, H., lizuka, T. \& 9 other authors (2004). Pseudoxanthomonas mexicana sp. nov. and Pseudoxanthomonas japonensis sp. nov., isolated from diverse environments, and emended descriptions of the genus Pseudoxanthomonas Finkmann et al. 2000 and of its type species. Int J Syst Evol Microbiol 54, 2245-2255.

Wayne, L. G., Brenner, D. J., Colwell, R. R. \& 9 other authors (1987). Report of the ad hoc committee on reconciliation of approaches to bacterial systematics. Int J Syst Bacteriol 37, 463-464.

Yang, P., Vauterin, L., Vancanneyt, M., Swings, J. \& Kersters, K. (1993). Application of fatty acid methylesters for the taxonomic analysis of the genus Xanthomonas. Syst Appl Microbiol 16, 47-71.

Yang, D.-C., Im, W.-T., Kim, M. K. \& Lee, S.-T. (2005). Pseudoxanthomonas koreensis sp. nov. and Pseudoxanthomonas daejeonensis sp. nov. Int J Syst Evol Microbiol 55, 787-791. 